\title{
Título da página electrónica: Fast Capitalism
}

Endereço: http://www.fastcapitalism.com/

José Manuel Mendes

\section{(2) OpenEdition}

\section{Journals}

Edição electrónica

URL: http://journals.openedition.org/rccs/914

DOI: $10.4000 /$ rccs.914

ISSN: 2182-7435

\section{Editora}

Centro de Estudos Sociais da Universidade de Coimbra

Edição impressa

Data de publição: 1 outubro 2006

Paginação: 179-180

ISSN: 0254-1106

Refêrencia eletrónica

José Manuel Mendes, «Título da página electrónica: Fast Capitalism », Revista Crítica de Ciências Sociais [Online], 75 | 2006, posto online no dia 01 outubro 2012, consultado o 22 setembro 2020. URL : http://journals.openedition.org/rccs/914 ; DOI : https://doi.org/10.4000/rccs.914 


\title{
Espaço Virtual
}

\author{
Títulos das páginas electrónicas: \\ Understanding Katrina: Perspectives from the Social Sciences \\ The Privatization of Risk \\ http://understandingkatrina.ssrc.org/ \\ http://privatizationofrisk.ssrc.org/
}

Estas duas páginas electrónicas apresentam-se como lugares de debate e de confronto de ideias em torno da temática do risco e das causas, impacto e dinâmicas pós-evento do furacão Katrina nos Estados Unidos. As páginas são da responsabilidade do Social Science Research Council, uma organização privada sem fins lucrativos sediada em Nova Iorque e que tem como objectivo principal contribuir para o desenvolvimento de ciências sociais com capacidade de intervenção no espaço público e nas políticas públicas.

As páginas em análise mais não são do que um reportório de artigos temáticos da autoria de reputados cientistas sociais. A que é dedicada ao furacão Katrina reúne contributos de grande qualidade em torno das questões relacionadas com os desastres, prevenção e dispositivos de emergência, e das lógicas económicas, sociais e políticas associadas a catástrofes ou acontecimentos extremos. Como se afirma explicitamente na apresentação da página, o que se pretende é mobilizar conhecimentos que vão para além das simples etiquetas de "desastre natural", "falhas de engenharia" ou outras análogas, e colocar no centro da discussão os processos de discriminação e de desigualdade e o acesso diferenciado e opressivo a uma cidadania plena. Dos artigos disponíveis, destaco os propostos por Steve Lukes e James Jasper.

A página "The Privatisation of Risk", com ênfase na abordagem económica, pretende analisar a tendência quase inexorável de retracção do provimento de bens públicos pelo Estado e da consequente produção de políticas e de narrativas em torno das virtudes da iniciativa privada. Merecem especial atenção os artigos de Leslie McCall e de Jacob Hacker.

\section{Título da página electrónica: Fast Capitalism \\ Endereço: http://www.fastcapitalism.com/}

Fast Capitalism é uma revista electrónica dedicada ao estudo do impacto das tecnologias de comunicação e da informação "rápida" na configuração das identidades pessoais e nos processos societais globais. Tem como editor principal Ben Agger, e congrega os mais importantes especialistas das ciências sociais e humanas anglo-saxónicos que se debruçam sobre estas temáticas.
Adoptando uma posição crítica, os editores pretendem promover uma reflexão fundamentada sobre os desafios que as novas tecnologias colocam à participação pública e à democracia. A visão crítica da nova cultura mediática obriga à produção de novos conceitos analíticos e de novas metodologias que reconstituam o carácter emancipatório do conhecimento e potenciem, sem 
demonizar ou celebrar, as novas tecnologias e os novos espaços de diálogo, mas também de vigilância e de controlo estatais.

Já foram editados três números desta publicação, tendo o último, de 2006, o título sugestivo "Bicycle Messengers and Fast Capitalism: An Old School Solution to the Needs of Techno-Capitalism”.

\section{Título da página electrónica: The Walter Benjamin Research Syndicate Endereço: http://www.wbenjamin.org/walterbenjamin.html}

Esta página procura ser um repertório de textos em torno da obra de Walter Benjamin e um incentivo à divulgação de trabalhos sobre a teoria crítica proposta por este autor. É editor da página Scott J. Thompson, docente do New College of California. No texto de apresentação, é referido que o objectivo central desta publicação electrónica é atender aos textos mais marginais de Walter Benjamin, excluídos ou pouco trabalhados na academia.

Embora a página não esteja estruturada de forma a permitir uma navegação orientada, o grafismo é apelativo e as secções oferecem excelentes conteúdos. As secções propostas são as seguintes: ligações (com uma lista de mais de 200 endereços relacionados com Walter Benjamin); traduções dos trabalhos de Walter Benjamin; recursos de investigação; artigos, ensaios e relatórios.

Dos artigos académicos disponíveis, merece especial referência o de Christopher
Rollason, "Globalisation and Particularism in the Work of José Saramago: the Symbolism of the Shopping-Mall in A Caverna". O principal recurso apresentado é a The Pansophist Electric Bibliothek, que compila um leque diversificado de textos disponíveis electronicamente. Esta biblioteca electrónica possui as seguintes entradas: bibliografia de Walter Benjamin; A Escola de Frankfurt; A filosofia alemã e a teoria social; História e literatura alemãs. Além da inventariação das obras clássicas, é apresentada uma lista de títulos recentes em torno das temáticas abrangidas por esta biblioteca. De forma a enriquecer os conteúdos oferecidos, teria sido interessante a introdução de uma secção com textos e obras comentados, de forma a orientar o leitor nas suas pesquisas sobre os temas em causa.

José Manuel Mendes jmomendes@netvisao.pt 